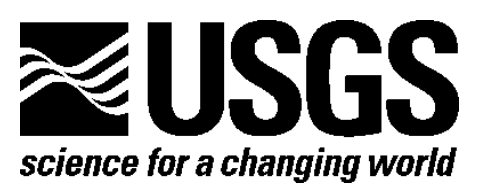

\title{
A Crosswalk of Mineral Commodity End Uses and North American Industry Classification System (NAICS) Codes
}

By James J. Barry, Grecia R. Matos, and W. David Menzie

Open-File Report 2015-1163

U.S. Department of the Interior

U.S. Geological Survey 


\section{U.S. Department of the Interior SALLY JEWELL, Secretary}

\section{U.S. Geological Survey Suzette M. Kimball, Acting Director}

U.S. Geological Survey, Reston, Virginia: 2015

For more information on the USGS-the Federal source for science about the Earth, its natural and living resources, natural hazards, and the environment-visit http://www.usgs.gov or call 1-888-ASK-USGS (1-888-275-8747)

For an overview of USGS information products, including maps, imagery, and publications, visit http://www.usgs.gov/pubprod

To order this and other USGS information products, visit http://store.usgs.gov

Any use of trade, firm, or product names is for descriptive purposes only and does not imply endorsement by the U.S. Government.

Although this information product, for the most part, is in the public domain, it also may contain copyrighted materials as noted in the text. Permission to reproduce copyrighted items must be secured from the copyright owner.

Suggested citation:

Barry, J.J., Matos, G.R., and Menzie, W.D., 2015, A crosswalk of mineral commodity end uses and North American Industry Classification System (NAICS) codes: U.S. Geological Survey Open-File Report 2015-1163, 4 p., plus 77 tables in 1 Excel file, http://dx.doi.org/10.3133/ofr20151163. 


\section{Contents}

Introduction

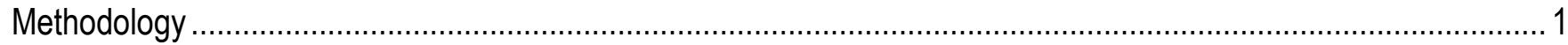

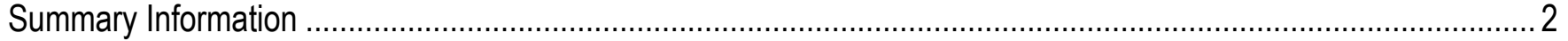

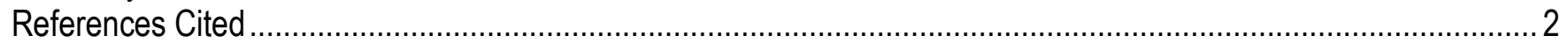

Appendix 1. Manufacturing Subsector NAICS Codes .................................................................................. 4

\section{Tables}

Tables are available in a separate Excel file.

1. Distribution of mineral commodities across North American Industry Classification System (NAICS) code subsectors and their value added to the GDP.

2. End uses of aluminum and corresponding North American Industry Classification System (NAICS) codes.

3. End uses of antimony and corresponding North American Industry Classification System (NAICS) codes.

4. End uses of asbestos and corresponding North American Industry Classification System (NAICS) codes.

5. End uses of barite and corresponding North American Industry Classification System (NAICS) codes.

6. End uses of alumina and bauxite and corresponding North American Industry Classification System (NAICS) codes.

7. End uses of beryllium and corresponding North American Industry Classification System (NAICS) codes.

8. End uses of bismuth and corresponding North American Industry Classification System (NAICS) codes.

9. End uses of boron and ferroboron and corresponding North American Industry Classification System (NAICS) codes.

10. End uses of bromine and corresponding North American Industry Classification System (NAICS) codes.

11. End uses of cadmium and corresponding North American Industry Classification System (NAICS) codes.

12. End uses of cement and corresponding North American Industry Classification System (NAICS) codes.

13. End uses of cesium and corresponding North American Industry Classification System (NAICS) codes.

14. End uses of chromium and corresponding North American Industry Classification System (NAICS) codes.

15. End uses of clay and corresponding North American Industry Classification System (NAICS) codes.

16. End uses of cobalt and corresponding North American Industry Classification System (NAICS) codes.

17. End uses of copper and corresponding North American Industry Classification System (NAICS) codes.

18. End uses of diamonds and corresponding North American Industry Classification System (NAICS) codes.

19. End uses of diatomite and corresponding North American Industry Classification System (NAICS) codes.

20. End uses of feldspar and corresponding North American Industry Classification System (NAICS) codes.

21. End uses of fluorspar and corresponding North American Industry Classification System (NAICS) codes.

22. End uses of gallium and corresponding North American Industry Classification System (NAICS) codes.

23. End uses of garnet and corresponding North American Industry Classification System (NAICS) codes.

24. End uses of gemstones and corresponding North American Industry Classification System (NAICS) codes.

25. End uses of germanium and corresponding North American Industry Classification System (NAICS) codes.

26. End uses of gold and corresponding North American Industry Classification System (NAICS) codes.

27. End uses of graphite and corresponding North American Industry Classification System (NAICS) codes.

28. End uses of gypsum and corresponding North American Industry Classification System (NAICS) codes.

29. End uses of hafnium and corresponding North American Industry Classification System (NAICS) codes.

30. End uses of helium and corresponding North American Industry Classification System (NAICS) codes.

31. End uses of indium and corresponding North American Industry Classification System (NAICS) codes.

32. End uses of iodine and corresponding North American Industry Classification System (NAICS) codes. 
33. End uses of iron and steel and corresponding North American Industry Classification System (NAICS) codes.

34. End uses of kyanite and corresponding North American Industry Classification System (NAICS) codes.

35. End uses of lead and corresponding North American Industry Classification System (NAICS) codes.

36. End uses of lime and corresponding North American Industry Classification System (NAICS) codes.

37. End uses of lithium and corresponding North American Industry Classification System (NAICS) codes.

38. End uses of magnesium and corresponding North American Industry Classification System (NAICS) codes.

39. End uses of manganese and corresponding North American Industry Classification System (NAICS) codes.

40. End uses of mercury and corresponding North American Industry Classification System (NAICS) codes.

41. End uses of mica and corresponding North American Industry Classification System (NAICS) codes.

42. End uses of molybdenum and corresponding North American Industry Classification System (NAICS) codes.

43. End uses of nickel and corresponding North American Industry Classification System (NAICS) codes.

44. End uses of niobium and corresponding North American Industry Classification System (NAICS) codes.

45. End uses of nitrogen (ammonia) and corresponding North American Industry Classification System (NAICS) codes.

46. End uses of peat and corresponding North American Industry Classification System (NAICS) codes.

47. End uses of perlite and corresponding North American Industry Classification System (NAICS) codes.

48. End uses of phosphate rock and corresponding North American Industry Classification System (NAICS) codes.

49. End uses of platinum-group metals and corresponding North American Industry Classification System (NAICS) codes.

50. End uses of potash and corresponding North American Industry Classification System (NAICS) codes.

51. End uses of pumice and corresponding North American Industry Classification System (NAICS) codes.

52. End uses of quartz crystal and corresponding North American Industry Classification System (NAICS) codes.

53. End uses of rare earth elements and corresponding North American Industry Classification System (NAICS) codes.

54. End uses of rhenium and corresponding North American Industry Classification System (NAICS) codes.

55. End uses of rubidium and corresponding North American Industry Classification System (NAICS) codes.

56. End uses of salt and corresponding North American Industry Classification System (NAICS) codes.

57. End uses of sand and gravel and corresponding North American Industry Classification System (NAICS) codes.

58. End uses of sand (industrial) and corresponding North American Industry Classification System (NAICS) codes.

59. End uses of selenium and corresponding North American Industry Classification System (NAICS) codes.

60. End uses of silicon and corresponding North American Industry Classification System (NAICS) codes.

61. End uses of silver and corresponding North American Industry Classification System (NAICS) codes.

62. End uses of soda ash and corresponding North American Industry Classification System (NAICS) codes.

63. End uses of strontium and corresponding North American Industry Classification System (NAICS) codes.

64. End uses of sulfur and corresponding North American Industry Classification System (NAICS) codes.

65. End uses of talc and pyrophyllite and corresponding North American Industry Classification System (NAICS) codes.

66. End uses of tantalum and corresponding North American Industry Classification System (NAICS) codes.

67. End uses of tellurium and corresponding North American Industry Classification System (NAICS) codes.

68. End uses of thallium and corresponding North American Industry Classification System (NAICS) codes. 
69. End uses of thorium and corresponding North American Industry Classification System (NAICS) codes.

70. End uses of tin and corresponding North American Industry Classification System (NAICS) codes.

71. End uses of titanium sponge and corresponding North American Industry Classification System (NAICS) codes.

72. End uses of titanium dioxide and corresponding North American Industry Classification System (NAICS) codes.

73. End uses of tungsten and corresponding North American Industry Classification System (NAICS) codes.

74. End uses of vanadium and corresponding North American Industry Classification System (NAICS) codes.

75. End uses of vermiculite and corresponding North American Industry Classification System (NAICS) codes.

76. End uses of zinc and corresponding North American Industry Classification System (NAICS) codes.

77. End uses of zirconium and corresponding North American Industry Classification System (NAICS) codes. 


\title{
A Crosswalk of Mineral Commodity End Uses and North American Industry Classification System (NAICS) Codes
}

\author{
By James J. Barry, Grecia R. Matos, and W. David Menzie
}

\section{Introduction}

This crosswalk is based on the premise that there is a connection between the way mineral commodities are used and how this use is reflected in the economy. Raw mineral commodities are the basic materials from which goods, finished products, or intermediate materials are manufactured or made. Mineral commodities are vital to the development of the U.S. economy and they impact nearly every industrial segment of the economy, representing 12.2 percent of the U.S. gross domestic product (GDP) in 2010 (U.S. Bureau of Economic Analysis, 2014). In an effort to better understand the distribution of mineral commodities in the economy, the U.S. Geological Survey (USGS) attempts to link the end uses of mineral commodities to the corresponding North American Industry Classification System (NAICS) codes.

The links between the end uses of mineral commodities and the NAICS codes provide an instrument for analyzing the use of mineral commodities in the economy. The crosswalk is also a guide, highlighting those industrial sectors in the economy that rely heavily on mineral commodities. The distribution of mineral commodities across the economy is dynamic and does differ from year to year. This report reflects a snapshot of the state of the economy and mineral commodities in 2010 .

\section{Methodology}

NAICS codes were created to facilitate analysis of industrial areas in the economy. Each NAICS code consists of six digits. The first two digits divide the economy into 20 industrial sectors. Subsectors, represented by the first three digits of the NAICS code, are economic units grouped together by similar production processes (see appendix 1 for the 21 manufacturing subsectors covering mineral commodity end uses). The fourth through sixth digits provide more narrow definitions of industry.

Minerals affect nearly every industrial segment of the economy. In this report, the USGS has developed tables of mineral commodities with the following broad end-use categories: Agricultural, Chemical, Construction/Building, Electrical/Electronic, Machinery, Manufacturing, Medical, Metallurgical, Transportation, and Other. These categories are further broken down to more specific uses and matched with their corresponding NAICS codes. At a minimum, the first three digits of the NAICS code are provided for each mineral commodity, and additional digits are provided when that level of detail was discernable for the end use.

End-use information for 2010 was gathered for most mineral commodities using data from the Mineral Commodity Summaries (U.S. Geological Survey, 2010), Minerals Yearbook (U.S. Geological Survey, 2012), and correspondence with USGS commodity specialists. If the quantity of the material or the percent of material usage is known, those data are provided in the table. Unless otherwise noted, 
percentages are based on total consumption and are a percentage that can be rolled-up within one of the broad categories.

\section{Summary Information}

Table 1 provides the distribution of mineral commodity uses across the subsectors defined by the three-digit NAICS codes. This table shows the value added to the GDP for each of these sectors and illustrates where individual mineral commodities impact the economy. Additionally, mineral commodities are noted by the percentage of their usage within subsectors. Mineral commodities with 50 percent or more usage within a subsector are represented in bold font. Those mineral commodities with a usage of at least 25 percent and less than 50 percent are in bold italics. Mineral commodities with less than 25 percent use are in italics. Mineral commodities below the dashed line and in normal font have end uses within the subsector, but the percentage and quantity are unknown. Many mineral commodities also have an asterisk notation. This signifies that the percentage of usage spans multiple industrial sectors, but the proportion of the mineral commodity in any individual sector is unknown.

Tables 2 through 77 show the end uses and associated NAICS codes for individual mineral commodities. Except where noted, the data source for tables is the U.S. Geological Survey Minerals Yearbook 2010. When the data are available, the quantity and percentage of use are shown. For consistency and to facilitate comparisons, all end uses were placed into the following general categories across all mineral commodities: Agricultural, Chemical, Construction/Building, Electrical/Electronic, Machinery, Manufacturing, Medical, Metallurgical, Transportation, and Other. More specific uses within these categories are presented with various levels of detail on the basis of how much is known about the individual mineral commodity's end uses.

\section{References Cited}

Aluminum Association, Inc., The, 2006, Shipments of aluminum semifabricated products, United States and Canada by end use: Arlington, Va., The Aluminum Association, Inc.

Cobalt Development Institute, The, 2011, Cobalt supply \& demand 2010, in Cobalt Facts: The Cobalt Development Institute, p. 53-58. [Also available at http:/www.thecdi.com/cdi/images/documents/ facts/Cobalt $\% 20$ Facts $\% 20-\% 20$ Supply\%20\%20Demand $\% 20-\% 2010 . p d f$.

Executive Office of the President, Office of Management and Budget, 2002, North American Industry Classification System: Lanham, Md., Bernan Press, 1419 p.

Johnson Matthey, 2011, Market data tables: Johnson Matthey Web site, accessed July 31, 2015, at http://www.platinum.matthey.com/services/market-research/market-data-tables.

Roskill Information Services Limited, 2010a, Multi-crystalline silicon-50\% rise in 2010 world production: Roskill's Letter from Japan, no. 421, September, p. 1-5.

Roskill Information Services Limited, 2010b, Multi-crystalline silicon-World production capacity forecast to rise by 10\% per year through 2013: Roskill's Letter from Japan, no. 411, November, p. $1-6$.

Roskill Information Services Limited, 2011, Zircon-Global industry markets and outlook: London, United Kingdom, Roskill Information Services Limited, 336 p.

U.S. Bureau of Economic Analysis, 2014, Value added by industry as a percentage of gross domestic product: U.S. Bureau of Economic Analysis Web page, accessed March 4, 2015, at http://www.bea.gov/industry/gdpbyind_data.htm.

U.S. Geological Survey, 2010, Mineral commodity summaries 2010: U.S. Geological Survey, 193 p. [Also available at http://minerals.usgs.gov/minerals/pubs/mcs/2010/mcs2010.pdf.] 
U.S. Geological Survey, 2012, Metals and minerals: U.S. Geological Survey Minerals Yearbook 2010, v. I, 1104 p. [Also available at http://minerals.usgs.gov/minerals/pubs/myb.html.]

Vulcan, Tom, 2009, Fluorspar-The cool mineral: Seeking Alpha, September 9, 2009, accessed August 15, 2012, at http://seekingalpha.com/article/160670-fluorspar-the-cool-mineral. 


\section{Appendix 1. Manufacturing Subsector NAICS Codes}

311 Food Manufacturing

312 Beverage and Tobacco Product Manufacturing

313 Textile Mills

314 Textile Product Mills

315 Apparel Manufacturing

316 Leather and Allied Product Manufacturing

321 Wood Product Manufacturing

322 Paper Manufacturing

323 Printing and Related Support Activities

324 Petroleum and Coal Products Manufacturing

325 Chemical Manufacturing

326 Plastics and Rubber Products Manufacturing

327 Nonmetallic Mineral Product Manufacturing

331 Primary Metal Manufacturing

332 Fabricated Metal Product Manufacturing

333 Machinery Manufacturing

334 Computer and Electronic Product Manufacturing

335 Electrical Equipment, Appliance, and Component Manufacturing

336 Transportation Equipment Manufacturing

337 Furniture and Related Product Manufacturing

339 Miscellaneous Manufacturing

See http://www.census.gov/cgi-bin/sssd/naics/naicsrch?chart=2012 for the complete list of all current NAICS codes and further breakdown of the manufacturing codes. 
ISSN 2331-1258 (online)

http://dx.doi.org/10.3133/ofr20151163 